\title{
Conexões e controvérsias no Instituto Nacional de Colonização e Reforma Agrária (Incra) de Marabá: o Estado como um ator heterogêneo
}

\author{
Camila Penna \\ Orientador: Prof. Dr. Marcelo Carvalho Rosa \\ Curso: Doutorado em Sociologia \\ Data da Defesa: 25.11.2013
}

0 tema desta tese é o Instituto Nacional de Colonização e Reforma Agrária (Incra), autarquia fundiária responsável por executar políticas de reforma agrária, colonização e desenvolvimento rural no Brasil. Os objetivos iniciais da pesquisa foram compreender como o órgão trabalha, e como ele se relaciona com os movimentos sociais rurais no processo de implementação das políticas de reforma agrária. A investigação foi conduzida a partir de observação etnográfica realizada entre outubro de 2011 e maio de 2012, na Superintendência Regional do Sul e do Sudeste do Pará (SR-27), localizada na cidade de Marabá. Com base na teoria do ator-rede de Bruno Latour, busquei traçar os agentes e as conexões que conformam a Superintendência de Marabá, intentando compreender os seus efeitos para o trabalho da regional. Foi possível concluir que a SR-27 é um órgão caracterizado por grande heterogeneidade de posições e de opiniões entre seus servidores, envoltos em múltiplas conexões que atravessam seu dia a dia de trabalho - o que gera efeitos na forma pela qual as políticas são executadas. A pesquisa também revelou que o cotidiano do órgão é marcado por controvérsias em torno de temas centrais, como o "tempo de casa", a interferência política no Incra, e a relação com os movimentos sociais. As posições, opiniões e ações dos servidores sobre estes temas afetam a forma como executam seu trabalho e, por conseguinte, a forma como as políticas de reforma agrária são efetivadas. Por fim, a pesquisa permitiu constatar que há uma participação intensa dos movimentos sociais rurais na rotina de trabalho da SR-27. Está em jogo uma relação de parceria, caracterizada por um processo de cooperação e de dependência, na qual os papéis do Estado e dos movimentos sociais estão em constante disputa.

Palavras-chave: Instituto Nacional de Colonização e Reforma Agrária (Incra); Estado; movimentos sociais; parceria; burocracia; políticas públicas; reforma agrária. 